\title{
A Model for Nitrogen Chemistry in Oxy-Fuel Combustion of Pulverized Coal
}

Hashemi, Hamid; Hansen, Stine; Toftegaard, Maja Bøg; Pedersen, Kim Hougaard; Jensen, Anker Degn; Dam-Johansen, Kim; Glarborg, Peter

\section{Published in:}

Energy \& Fuels

Link to article, DOI:

10.1021/ef200853t

Publication date:

2011

Document Version

Publisher's PDF, also known as Version of record

Link back to DTU Orbit

Citation (APA):

Hashemi, H., Hansen, S., Toftegaard, M. B., Pedersen, K. H., Jensen, A. D., Dam-Johansen, K., \& Glarborg, P. (2011). A Model for Nitrogen Chemistry in Oxy-Fuel Combustion of Pulverized Coal. Energy \& Fuels, 25(10), 4280-4289. https://doi.org/10.1021/ef200853t

\section{General rights}

Copyright and moral rights for the publications made accessible in the public portal are retained by the authors and/or other copyright owners and it is a condition of accessing publications that users recognise and abide by the legal requirements associated with these rights.

- Users may download and print one copy of any publication from the public portal for the purpose of private study or research.

- You may not further distribute the material or use it for any profit-making activity or commercial gain

- You may freely distribute the URL identifying the publication in the public portal 


\title{
A Model for Nitrogen Chemistry in Oxy-Fuel Combustion of Pulverized Coal
}

\author{
Hamid Hashemi, Stine Hansen, Maja B. Toftegaard, Kim H. Pedersen, Anker D. Jensen, Kim Dam-Johansen, \\ and Peter Glarborg*
}

Department of Chemical and Biochemical Engineering, Technical University of Denmark, 2800 Lyngby, Denmark

Supporting Information

ABSTRACT: In this work, a model for the nitrogen chemistry in the oxy-fuel combustion of pulverized coal has been developed. The model is a chemical reaction engineering type of model with a detailed reaction mechanism for the gas-phase chemistry, together with a simplified description of the mixing of flows, heating and devolatilization of particles, and gas-solid reactions. The model is validated by comparison with entrained flow reactor results from the present work and from the literature on pulverized coal combustion in $\mathrm{O}_{2} / \mathrm{CO}_{2}$ and air, covering the effects of fuel, mixing conditions, temperature, stoichiometry, and inlet $\mathrm{NO}$ level. In general, the model provides a satisfactory description of $\mathrm{NO}$ formation in air and oxy-fuel combustion of coal, but under some conditions, it underestimates the impact on $\mathrm{NO}$ of replacing $\mathrm{N}_{2}$ with $\mathrm{CO}_{2}$. According to the model, differences in the $\mathrm{NO}$ yield between the oxy-fuel combustion and the conventional combustion of pulverized coal can mostly be attributed to the recycling of NO (reburning effect) and to changes in the mixing patterns between fuel and oxygen. For pulverized-fuel combustion at high temperatures, we think that NO is mainly reduced by heterogeneous reactions involving both char and soot. Here, the tar yield of the volatiles is mainly converted to soot and $\mathrm{H}_{2}$, limiting the concentration of hydrocarbons and thereby the importance of gas-phase removal of NO. Our work emphasizes the need for accurate descriptions of mixing, volatile composition (fate of tar), and heterogeneous reactions. Furthermore, more work is desirable on the reduction of NO by CO on char at higher temperatures.

\section{INTRODUCTION}

An effective measure to reduce green house gas emissions from combustion is carbon dioxide capture and storage. This process involves the separation of $\mathrm{CO}_{2}$ from industrial and energy-related sources, transport to a storage location, and long-term isolation from the atmosphere. The so-called oxy-fuel combustion technology for pulverized fuel combustion is a promising approach for facilitating $\mathrm{CO}_{2}$ sequestration. ${ }^{1,2}$ In this approach, a blend of oxygen typically of greater than $90 \%$ purity and recycled flue gas is used for combustion of the fuel. Thereby, the combustion process generates a flue gas consisting mainly of $\mathrm{CO}_{2}$ and $\mathrm{H}_{2} \mathrm{O}$, allowing for a simple downstream removal of $\mathrm{CO}_{2}$. The recycled flue gas replaces the $\mathrm{N}_{2}$ in the combustion air and serves to lower the flame temperature and keep up the gas volume through the boiler.

Oxy-fuel combustion with recirculation of flue gases was proposed initially by Horn and Steinberg ${ }^{3}$ and Abraham et al. ${ }^{4}$ The characteristics of oxy-fuel combustion differ from air combustion in several aspects, such as the gaseous pollutant formation and emission. ${ }^{1,2}$ Particularly, the formation of nitrogen oxides in oxy-fuel combustion has attracted interest and is treated in significant detail in two reviews. ${ }^{2,5}$ On the basis of reported experimental results, Toftegaard et al. ${ }^{2}$ conclude that the amount of $\mathrm{NO}_{x}$ emitted from oxy-fuel plants can be reduced to somewhere between one-third and half of that from combustion in air. Normann et al. ${ }^{5}$ state that, for a first generation of oxy-fuel power plants, conventional primary $\mathrm{NO}_{x}$ control should be sufficient to meet today's emission regulations, if they are based on emission per unit of fuel supplied. However, according to Normann et al., there are several opportunities for new methods of $\mathrm{NO}_{x}$ control in oxy-fuel plants, depending on future emission and storage legislation for carbon capture schemes, and they call for improved understanding of, among other things, the influence of the parameters of oxy-combustion on nitrogen chemistry.

$\mathrm{NO}_{x}$ emission rates during oxy-fuel combustion compared to air-firing have been reported for different fuels in laminar flow reactors, ${ }^{6,7}$ entrained-flow reactors, ${ }^{8-12}$ and swirling flames. ${ }^{13-20}$ In studies with recirculation of flue gas, $\mathrm{NO}_{x}$ is generally reduced compared to the case of conventional combustion, but the level of reduction depends on the reactor/burner design and the reaction conditions. ${ }^{2}$ In once-through studies (i.e., without recirculation of $\mathrm{NO}), \mathrm{NO}_{x}$ has been reported to either increase or decrease as air is replaced with an $\mathrm{O}_{2} / \mathrm{CO}_{2}$ mixture. $^{2}$

Reported modeling work on $\mathrm{NO}_{x}$ in oxy-fuel combustion has largely been limited to gaseous fuels. ${ }^{6,7,17,21}$ Models for oxy-fuel combustion of coal have relied on computational fluid dynamics (CFD) codes with simplified schemes for the nitrogen chemistry. $^{22,23}$ The simplified schemes used have a limited accuracy, ${ }^{24-26}$ and these studies have not been able to fully explain the considerable variation in $\mathrm{NO}$ emissions reported for different oxy-fuel configurations.

The objective of the present work is to develop a chemical engineering model for simulation of the $\mathrm{NO}_{x}$ formation and reduction in the combustion zone during coal combustion under oxy-fuel conditions. It involves a detailed description of the

Received: June 9, 2011

Revised: September 1, 2011

Published: September 03, 2011 


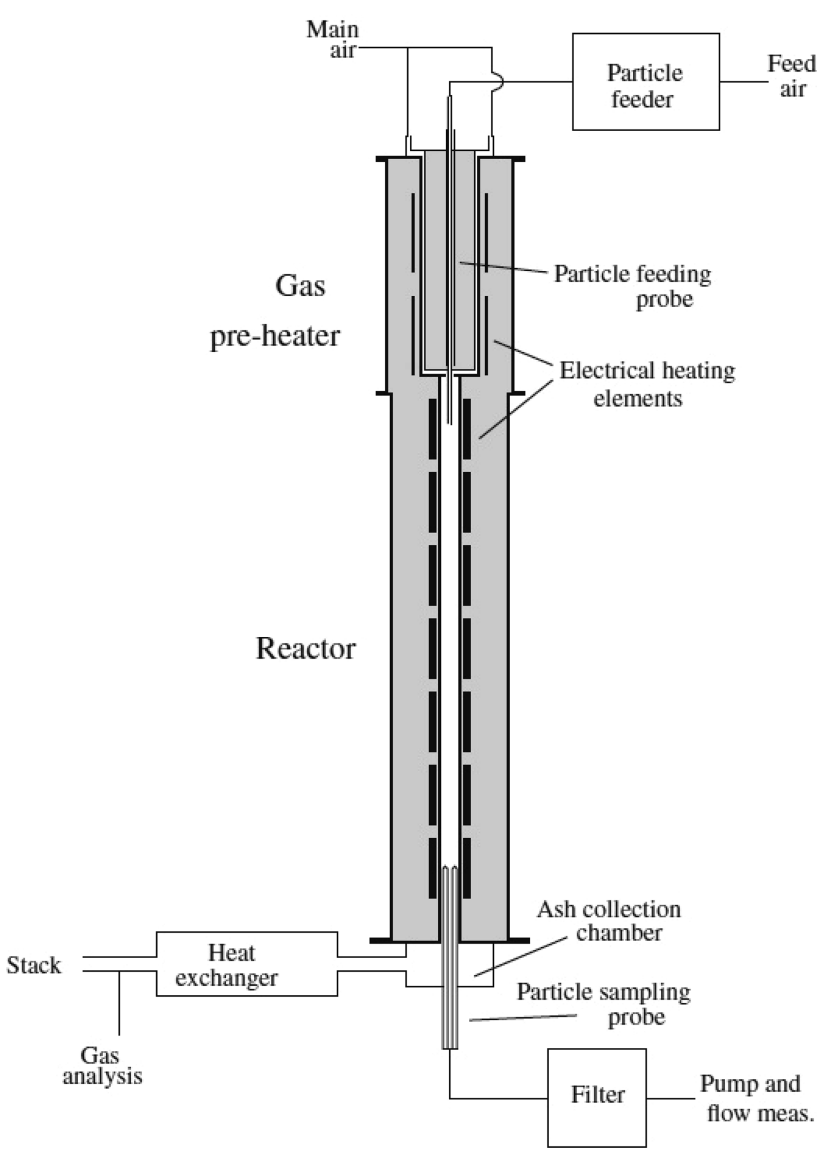

Figure 1. Sketch of the entrained flow reactor.

gas-phase chemistry together with a simplified description of mixing, devolatilization, and gas-solid reactions. The aim is to predict $\mathrm{NO}$ as a function of coal type and process conditions. The model is validated by comparison with entrained flow reactor data from the present work as well as from the literature. The rate limiting steps in NO formation and reduction in the oxy-fuel combustion of coal are discussed, and subsets of the model that require a better understanding are identified.

\section{EXPERIMENTAL SETUP}

The experimental setup and procedure have been described elsewhere, ${ }^{27}$ and only a brief description is given here. A schematic illustration of the entrained flow reactor is seen in Figure 1. The reactor is a cylindrical ceramic tube, $8 \mathrm{~cm}$ in diameter and $2 \mathrm{~m}$ long. It is electrically heated to a wall temperature of typically $1300{ }^{\circ} \mathrm{C}$ in the top and $1400{ }^{\circ} \mathrm{C}$ in the bottom. The pulverized coal is introduced in the top of the reactor through a water-cooled probe, along with a fraction of the oxidizer stream. The main part of the oxidizer is preheated to $1100{ }^{\circ} \mathrm{C}$ in the preheat section before entering the reaction zone. Part of the flue gas is sampled through a water-cooled particle collection probe with a sampling diameter of $3.2 \mathrm{~cm}$, located in the bottom of the reactor. The sampled particles are collected on a filter. The remaining flue gas is cooled downstream of the reactor and analyzed for $\mathrm{O}_{2}, \mathrm{CO}, \mathrm{CO}_{2}$, and $\mathrm{NO}$ using standard gas analyzers. The monitored compounds are reported as single average values for each experimental run.

\section{MODEL}

Conceptually, the present model for oxy-fuel combustion of coal is based on earlier reported work on reburning with coal ${ }^{28}$ and biomass. ${ }^{29}$
It involves a detailed reaction mechanism for gas-phase hydrocarbon/ NO chemistry, together with a simplified description of mixing and submodels for devolatilization and gas-solid reactions involving char and soot. The following sections present a description of the submodels used in the present modeling approach.

Mixing. The time scales for nitrogen chemistry in combustion are comparable to the mixing times between primary and secondary flows in pulverized-fuel burners. In modeling, a satisfactory description of the mixing process is important. The burners typically involve a rich-lean transition, and an assumption of instantaneous mixing may lead to considerable errors in the predicted NO levels. Previous modeling work on reburning with gaseous ${ }^{30,31}$ and solid fuels ${ }^{28,29}$ indicates that a

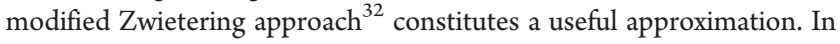
this approach, the secondary flow containing most of the oxidizer is gradually entrained into the primary flow with the main fuel (coal) and carrier gas, assuming an exponential mixing rate. The mixing rate, derived from an estimated or measured mixing time, is then given $\mathrm{as}^{30}$

$$
\frac{\mathrm{d} m_{\text {prim }}}{\mathrm{d} t}=k m_{\mathrm{sec}}
$$

Here, $m_{\text {prim }}$ and $m_{\mathrm{sec}}$ are the masses of the primary and secondary flows, respectively. With this assumption, the mass flow of the fuel jet at a given time is expressed by the following equation:

$$
m_{\text {prim }}=m_{\text {prim }, 0}+m_{\text {sec }, 0}(1-\exp (-k t))
$$

We assume in the model that the fuel jet is heated rapidly by penetration of the hot bulk fluid. Even though the Zwietering approach does not physically describe the behavior in the mixing region, it has provided good results for gas reburning ${ }^{30}$ and volatile $\mathrm{N}$ oxidation. ${ }^{33} \mathrm{It}$ captures an essential feature of the mixing, that is, that the volatile nitrogen and part of the recirculated NO under oxy-fuel conditions react initially under conditions going from fuel-rich (early stages of entrainment) to typically overall lean (full mixing).

Devolatilization. The devolatilization of solid fuels is mainly a thermal process, and differences in the volatile yields and composition between air-firing and oxy-fuel conditions are not expected. Niksa and $\mathrm{Lau}^{34}$ discussed the individual influences of heating rate and coal rank on the rate of pyrolysis. They concluded that, for coals of ranks lignite through high volatile bituminous, the rank variations are modest at high heating rates. This is in agreement with other results from the literature. ${ }^{35-37}$ Niksa and Lau found that, at heating rates faster than $1000 \mathrm{~K} / \mathrm{s}$, the influence of increasing the rate is minor. The disagreement in the literature among the rates of pyrolysis measured at fast heating rates of $10^{3}-10^{5} \mathrm{~K} / \mathrm{s}$ can probably be ascribed to uncertainties in the particle temperature determinations. ${ }^{36}$ At pulverized coal conditions, with high temperatures and heating rates, it is thus conceivable that the devolatilization rate can be assumed to be independent of the coal type and heating rate.

In the current model, the pyrolysis is described by a two-step Arrhenius model, following Ubhayakar et al. ${ }^{37}$ It consists of a reaction with a low activation energy significant at low temperatures $(<1200 \mathrm{~K})$ and a high activation energy reaction important at higher temperatures. The two-step model thus takes into account that the pyrolysis occurs over a range of temperatures with different activation energies.

Under conditions typical of pulverized fuel combustion (1500-1900 K), the volatiles have been reported to consist largely of $\mathrm{CO}$ and $\mathrm{H}_{2}$, together with soot/tar and a minor amount of hydrocarbons. ${ }^{38}$ The soot/tar yield ranges from 15 to 35 wt $\%$ of the original coal (daf) for bituminous and subbituminous coals, ${ }^{38-40}$ whereas it is lower for lignite, 5-20 wt \%. ${ }^{39,40}$ The soot/tar yields appear to be constant in the temperature range $1480-1900 \mathrm{~K}, 39,40$ with the soot fraction increasing with temperature. The soot formed has an initial diameter of about $25 \mathrm{~nm},{ }^{41}$ but by agglomeration and surface growth, the diameter will reach sizes of $200-800 \mathrm{~nm}$ during time scales of $100 \mathrm{~ms}$. In the model, 
we assume that all of the tar cracks to form soot, while the soot yield from reactions of light hydrocarbon volatiles can be neglected.

In the present model, it is assumed that all hydrogen and oxygen are released in the volatiles, while nitrogen is distributed among volatiles and char according to the mass ratio between them. Carbon atoms are distributed in a way to satisfy the overall mass balance between volatiles and char. To estimate the composition of the volatile gases, measurements from published sources $38,39,42,43$ have been used as a guideline. However, as a result of differences in composition and heating rate, the composition of volatiles for the present coals may deviate from published data for coals of similar rank

Tar is found by various authors to be the main shuttle for coal nitrogen. The nitrogen is thus released with the tar in the initial pyrolysis, where the nitrogen is found mainly in pyrrolic and pyridinic structures. $^{44-46}$ Thermal cracking of tar at temperatures above 1400 $\mathrm{K}$ facilitates ring-opening and fast release of nitrogen mainly as $\mathrm{HCN}{ }^{45}$ In the model, the volatile nitrogen is assumed to be found only as $\mathrm{HCN}$. It has been shown that a fraction of the coal nitrogen is incorporated into soot, ${ }^{39}$ but the fate of the soot nitrogen is unknown. In line with previous work, ${ }^{28,47}$ the soot is modeled as pure carbon. The fraction of HCN in the volatiles is calculated from the nitrogen release during devolatilization.

Volatile Oxidation. The model subset for the oxidation of the gaseous volatile species is adopted directly from work by Glarborg and co-workers. ${ }^{6,7,48}$ It is a detailed chemical kinetic mechanism, including 97 species in 778 reactions. The reaction mechanism is mostly based on work on the methane/ammonia reaction system in flow reactors ${ }^{49}$ and low-pressure flames. ${ }^{50}$ The reaction mechanism draws on results from the oxidation of $\mathrm{CO} / \mathrm{H}_{2},{ }^{51} \mathrm{C}_{1}-\mathrm{C}_{2}$ hydrocarbons, ${ }^{48,52} \mathrm{NH}_{3},{ }^{49,50}$ and $\mathrm{HCN},{ }^{53}$ as well as interactions of these components. ${ }^{50,54,55}$

The model has been validated against experimental data obtained for oxidation of methane with or without $\mathrm{NH}_{3}$ or $\mathrm{NO}$ in both $\mathrm{O}_{2} / \mathrm{N}_{2}$ and $\mathrm{O}_{2} /$ $\mathrm{CO}_{2}$ at temperatures in the range $1173-1773 \mathrm{~K}^{6,7,48}$ It contains an improved $\mathrm{CO} / \mathrm{CO}_{2}$ subset, which chemically activates the otherwise inert $\mathrm{CO}_{2}{ }^{48}$

Soot Reactions. Because soot constitutes a major fraction of the volatiles, reactions of these particles are potentially important. Soot oxidation occurs by reaction with $\mathrm{O}_{2}^{56}$ or oxygen-containing radicals $(\mathrm{OH}$ and $\mathrm{O}) .{ }^{57,58}$ Soot is very active in reducing $\mathrm{NO}$ at flame temperatures ${ }^{58,59}$ in a reaction that produces $\mathrm{CO}$ and $\mathrm{N}_{2} \cdot{ }^{58}$ Shock tube determinations of the reaction probability ${ }^{58,59}$ are in good agreement.

The soot reaction subset of the present model includes the Nagle and Strickland-Constable ${ }^{56}$ oxidation mechanism for reaction with $\mathrm{O}_{2}$ and the reaction of soot with NO. Reactions of soot with the $\mathrm{O} / \mathrm{H}$ radical pool have been neglected. For the reaction with NO, products and reaction probability were adopted from von Gersum and Roth. ${ }^{58}$ The calculation of the collision number was based on soot particles of $30 \mathrm{~nm}$. This corresponds to a surface area of $100 \mathrm{~m}^{2} / \mathrm{g}$, which is used in the Nagle and Strickland-Constable mechanism.

Char Reactions. In conventional pulverized coal combustion, char is largely oxidized by a reaction with molecular oxygen

$$
\text { char }+\frac{1}{2} \mathrm{O}_{2} \rightarrow \mathrm{CO}
$$

Under oxy-fuel combustion conditions, gasification reactions involving $\mathrm{CO}_{2}$ and $\mathrm{H}_{2} \mathrm{O}$ are more likely to contribute to the consumption of char particles, because these species are present in large concentrations. However, data from our laboratory ${ }^{60}$ indicate that these reactions play, at most, a very minor role in char oxidation at conditions representative of pulverized fuel combustion. In the present model, char $+\mathrm{O}_{2}$ is considered to be the only step active in oxidizing the char. Expressed in terms of the intrinsic rate coefficient $k_{\mathrm{char}+\mathrm{O}_{2}}$, the rate of the reaction is

$$
r_{\text {char }+\mathrm{O}_{2}}=k_{\text {char }}+\mathrm{O}_{2}\left[\mathrm{O}_{2}\right]^{n} \quad\left[\mathrm{~g} / \mathrm{cm}^{2} \mathrm{~s}\right]
$$

The reaction order $n$ is mostly one at high temperatures, where the dissociative adsorption of $\mathrm{O}_{2}$ onto the char surface is often rate controlling. Smith ${ }^{61}$ estimated intrinsic reactivities for a range of porous carbons ranging from lignite through bituminous and anthracite coals to purified carbons. He found that under conditions of pulverized fuel combustion, with temperatures above $1100 \mathrm{~K}$, there is a reasonable agreement between the rates for bituminous coals and lignite/brown coals. Adopting his expression approach, the rate constant for oxidation of the char surface at a partial pressure of $\mathrm{O}_{2}$ of $1 \mathrm{~atm}^{62}$ is

$$
k_{\text {char }+\mathrm{O}_{2}}=305 \exp \left(\frac{-21565}{T}\right) \quad\left[\mathrm{g} / \mathrm{cm}^{2} \mathrm{~s}\right]
$$

The rate of char oxidation is then modeled using the following equation, assuming a first-order dependency in $\mathrm{O}_{2}{ }^{28}$ and neglecting external mass transfer limitations

$$
-r=\eta k_{\text {char }+\mathrm{O}_{2}} P_{\mathrm{O}_{2}} A_{\text {int }}[\mathrm{char}] \quad\left[\mathrm{mol}_{\mathrm{C}} \mathrm{m}^{-3} \mathrm{~s}^{-1}\right]
$$

Here, $\eta$ is the effectiveness factor (dimensionless), $A_{\text {int }}$ is the specific intrinsic surface area of the char particle $\left(\mathrm{m}^{2} \mathrm{~kg}^{-1}\right), P_{\mathrm{O}_{2}}$ is the partial pressure of oxygen at the char particle surface (atm), and [char] is the number of moles of char per unit volume of gases $\left(\mathrm{mol} \mathrm{m}^{-3}\right)$. The effectiveness factor represents the diffusion resistance against oxygen inside the pores on the char surface, and it was calculated according to the model originally suggested by Thiele. ${ }^{63}$ The required effective diffusion coefficient, as well as the estimate of the char porosity, was calculated based on the work of Johnsson and Jensen. ${ }^{64}$ Effects of differences between coals regarding reactivity, surface area, and porosity were assumed to be negligible. At the conditions of the present work, the value of $\eta$ was in the range $0.4-0.9$, decreasing with increasing temperature. For all coals, the particle intrinsic surface area was assumed equal to $100 \mathrm{~m}^{2} \mathrm{~g}^{-1}$, based on the literature data. ${ }^{65,66}$

The mechanism of the char- $\mathrm{N}$ oxidation and the selectivity toward $\mathrm{NO}$ and $\mathrm{N}_{2}$ under combustion conditions are still in dispute. Reported conversions of char-N to NO range from below 30 to almost $100 \%{ }^{45}$ Pohl et al. ${ }^{46}$ reported char-N to NO conversion efficiencies of $10-25 \%$ for lignite and bituminous coal under pulverized fuel combustion conditions. On the basis of these and similar results, it is common in modeling to assume a fixed char-N conversion to NO, for instance $20 \%$, with the rest being released as $\mathrm{N}_{2}$. However, this simple approach does not reflect the actual processes involved in the char- $\mathrm{N}$ oxidation and, thereby, does not provide reliable results outside the range of conditions tested. The combustion of small, highly devolatilized char particles at single particle conditions $\left(1000-1400 \mathrm{~K}, 5-20 \% \mathrm{O}_{2}\right)$ has shown that char nitrogen is oxidized to NO with a yield of $75-100 \% .{ }^{67-72}$ This indicates that nitrogen in char is largely oxidized to $\mathrm{NO}$ and that $\mathrm{NO}$ yields far below $100 \%$ are caused by reduction of $\mathrm{NO}$ in the pores of the char particle in which the NO was formed or by a reaction with other char particles.

In the present model, we assume that the char- $\mathrm{N}$ is oxidized to $\mathrm{NO}$, with a rate similar to that of the carbon oxidation. In this way, the overall NO yield from char oxidation becomes very dependent on the subsequent reduction of $\mathrm{NO}$ on the char surface. This reaction has been widely studied. ${ }^{45,46,65,66,73,74}$ The rate constant proposed by Aarna and Suuberg $^{66}$ for the char + NO reaction, obtained from averaging a large amount of data, agrees within a factor of 10 to most reported values. These data were all obtained with char, which was prepared separately, and they represent steady state values for the char + NO reaction. However, work by the authors, ${ }^{70,75}$ obtained with fresh char directly in continuation of pyrolysis, indicates a reaction rate that is $10-100$ times larger than the Aarna and Suuberg rate constant. The higher value represents a transient char reactivity toward NO; with time, the rate of the char $+\mathrm{NO}$ reaction decreases as a result of thermal annealing and approaches the steady-state value reported in other studies.

Because the thermal deactivation of the char may decrease the rate of NO reduction on the char surface considerably, it is necessary to consider the thermal history of the char. In the present work, with chars 
Table 1. Proximate and Ultimate Analyses of Coals (wt \% $)^{a}$

\begin{tabular}{|c|c|c|c|c|c|c|c|c|c|}
\hline \multirow[b]{2}{*}{ coal } & \multicolumn{4}{|c|}{$\begin{array}{l}\text { proximate } \\
\text { analysis }\end{array}$} & \multicolumn{5}{|c|}{$\begin{array}{c}\text { ultimate } \\
\text { analysis (daf) }\end{array}$} \\
\hline & moisture & ash & VM & $\mathrm{FC}$ & $\mathrm{C}$ & $\mathrm{H}$ & $\mathrm{O}$ & $\mathrm{N}$ & S \\
\hline Bit 1 & 0.21 & 15.36 & 27.6 & 56.83 & 84.31 & 5.33 & 8.15 & 1.49 & 0.72 \\
\hline Bit 2 & & 2.0 & 48.0 & 50.0 & 73.5 & 5.2 & 18.8 & 1.4 & 1.1 \\
\hline Bit 3 & 5.82 & 22.65 & 30.3 & 41.23 & 77.86 & 5.42 & 14.85 & 1.05 & 0.82 \\
\hline lignite & 14.72 & 10.64 & 35.69 & 38.95 & 73.45 & 5.88 & 19.54 & 0.84 & 0.29 \\
\hline
\end{tabular}

${ }^{a}$ Bit 1: Polish bituminous coal used in the present experiments. Bit 2: high volatile bituminous coal used by $\mathrm{Hu}$ et al. ${ }^{8}$ Bit 3: Tiefa bituminous coal used by Jiang et al. ${ }^{11}$ Lignite: Neimenggu lignite used by Jiang et al. ${ }^{11}$

produced in situ and reactor residence times of a few seconds, the chars will be very reactive. Following Garijo et al., ${ }^{75}$ the rate of NO reduction on char is given as

$$
-r_{\mathrm{NO}}=k_{\mathrm{char}+\mathrm{NO}}[\mathrm{char}][\mathrm{NO}]^{0.33} \quad\left[\mathrm{~mol}_{\mathrm{NO}} \mathrm{m}^{-3} \mathrm{~s}^{-1}\right]
$$

where

$k_{\text {char }+\mathrm{NO}}=\left(4.7 \times 10^{4}\right) \mathrm{MW}_{\text {char }} \exp \left(\frac{-13430}{T}\right) \quad\left[\mathrm{m} \mathrm{s} \mathrm{mol}^{-0.33}\right]$

$\mathrm{MW}_{\text {char }}$ is the molecular weight of char $\left(\mathrm{kg} \mathrm{mol}^{-1}\right)$. Similar to the case of char $+\mathrm{O}_{2}$, we apply an effectiveness factor, $\eta_{\mathrm{NO}}$, for $\mathrm{NO}$ reduction. To calculate $\eta_{\mathrm{NO}}$, the same procedure that was used for char oxidation was followed. The (small) difference in the diffusion coefficient was taken into account. Nitric oxide not only comes from the bulk (as does oxygen) but is also formed in the pores during char oxidation. This makes a difference for larger particles, but because our particles are quite small, the effectiveness $\eta_{\mathrm{NO}}$ remains near unity for most cases and the error of our results should be small.

\section{RESULTS AND DISCUSSION}

The simulations for oxy-fuel combustion of coal are conducted with the CHEMKIN 4.1 package. ${ }^{76}$ In the model, mixing, pyrolysis, and gas - solid reactions are represented by expressions that can be handled in CHEMKIN. The CHEMKIN format model is available in the Supporting Information.

The model is validated against experimental data obtained in entrained-flow reactors (EFRs). Despite its complexities, the EFR constitutes a more controlled environment than turbulent swirling pulverized-fuel flames. The EFR data are drawn partly from the present work and partly from the literature. The results cover a range of coals, equivalence ratios, temperatures, and mixing configurations. The EFR results from the present work are characterized by the initial segregation of a primary flow containing the coal/carrier gas and a secondary flow with the remaining oxidizer. In the EFR experiments from the literature, drawn from $\mathrm{Hu}$ et al. ${ }^{8}$ and Jiang et al., ${ }^{11}$ the fuel and oxidizer flows were premixed.

Table 1 lists the ultimate and proximate analyses of the coals used in the entrained-flow reactor experiments. For the Polish coal (Bit 1) used in the present experiments, we estimated the volatile yield by following the correlations of Neoh and Gannon. ${ }^{42}$ For the other coals, we used the volatile yields from the proximate analysis, as stated by the authors. ${ }^{8,11}$

Table 2 lists the estimated volatile compositions for the four coals. As none of these compositions have been determined experimentally, we rely on analogy with volatile compositions measured for coals of similar rank, as described above. However,
Table 2. Estimated Molar Volatile Composition for Coals ${ }^{a}$

\begin{tabular}{lrrrr} 
& \multicolumn{5}{c}{ coal } \\
\cline { 2 - 5 } species & Bit 1 & Bit 2 & Bit 3 & lignite \\
$\mathrm{C}_{\text {soot }}$ & 41.60 & 28.36 & 26.63 & 20.88 \\
$\mathrm{H}_{2}$ & 30.08 & 38.52 & 44.43 & 45.45 \\
$\mathrm{CO}_{2}$ & 1.00 & 3.26 & 2.05 & 3.93 \\
$\mathrm{CO}$ & 6.27 & 8.53 & 8.45 & 9.83 \\
$\mathrm{CH}_{4}$ & 8.02 & 3.76 & 4.87 & 4.42 \\
$\mathrm{C}_{2} \mathrm{H}_{4}$ & 7.27 & 1.76 & 1.54 & 2.46 \\
$\mathrm{H}_{2} \mathrm{O}$ & 4.51 & 14.56 & 11.27 & 12.29 \\
$\mathrm{HCN}$ & 1.25 & 1.25 & 0.77 & 0.74
\end{tabular}

${ }^{a}$ Bit 1: Polish bituminous coal used in the present experiments. Bit 2: high volatile bituminous coal used by $\mathrm{Hu}$ et al. ${ }^{8}$ Bit 3: Tiefa bituminous coal used by Jiang et al. ${ }^{11}$ Lignite: Neimenggu lignite used by Jiang et al. ${ }^{11}$

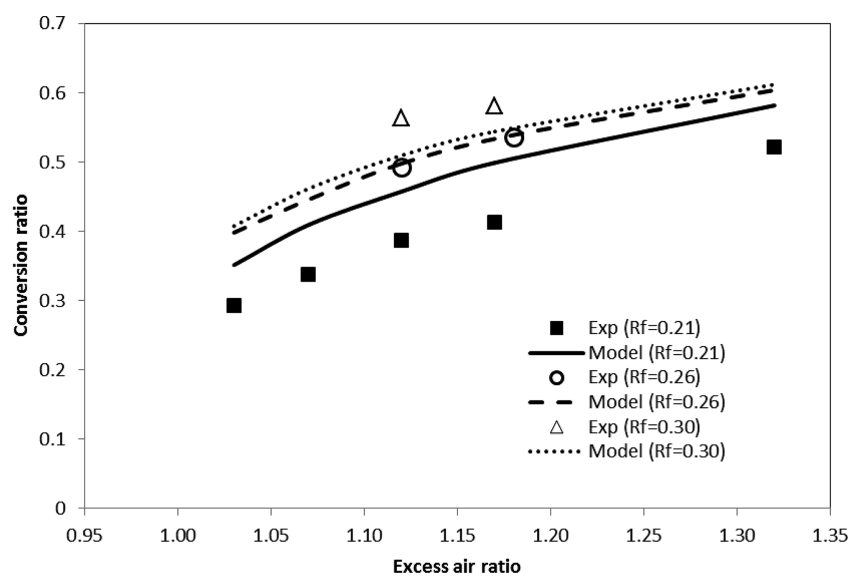

Figure 2. Comparison of measured and predicted fuel-N to NO ratios as a function of the excess air ratio and the feed ratio in coal combustion in air, in an entrained flow reactor. The experimental data (present work) are shown as symbols, while the modeling predictions are shown as lines. The experiments were conducted with a Polish bituminous coal (Bit $1,21 \mu \mathrm{m}$ ) at a wall temperature of $1623 \mathrm{~K}$ and a gas residence time

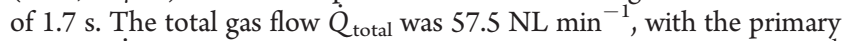
gas feed $\dot{Q}_{\text {feed }}$ being $12\left(R_{\mathrm{f}}=0.21\right), 15\left(R_{\mathrm{f}}=0.26\right)$, or $17.4 \mathrm{NL} \mathrm{min}{ }^{-1}$ $\left(R_{\mathrm{f}}=0.29\right)$. The coal feeding rate was $5.9-7.6 \mathrm{~g} \mathrm{~min}^{-1}$. Both primary and secondary gases consisted of $21 \% \mathrm{O}_{2}$ in $\mathrm{N}_{2}$.

because of differences in composition, heating rate, and final temperature, the actual volatile compositions may deviate considerably from our estimate. In particular, the assumption that tar is largely converted into soot and $\mathrm{H}_{2}$, as has been observed at high-temperature pulverized coal pyrolysis, ${ }^{38,39,42,43}$ may not apply to the conditions of all the EFR experiments used for model validation. Here, as a result of lower temperatures, the tar could be expected to yield hydrocarbons during cracking, rather than soot and $\mathrm{H}_{2}$.

EFR Results from the Present Work. The conditions used for air and oxy-fuel combustion experiments in the entrained-flow reactor are listed in the Supporting Information. The Polish coal (Bit 1) used was finely ground to a mean particle size of $21.3 \mu \mathrm{m}$, with $90 \%$ of the particles smaller that $100 \mu \mathrm{m}$ and $10 \%$ smaller than $5 \mu \mathrm{m}$. The term NL $\min ^{-1}$ (Table 1 of the Supporting Information and elsewhere) refers to the volume flow in liters per minute at standard temperature and pressure $(273 \mathrm{~K}, 1 \mathrm{~atm})$. 


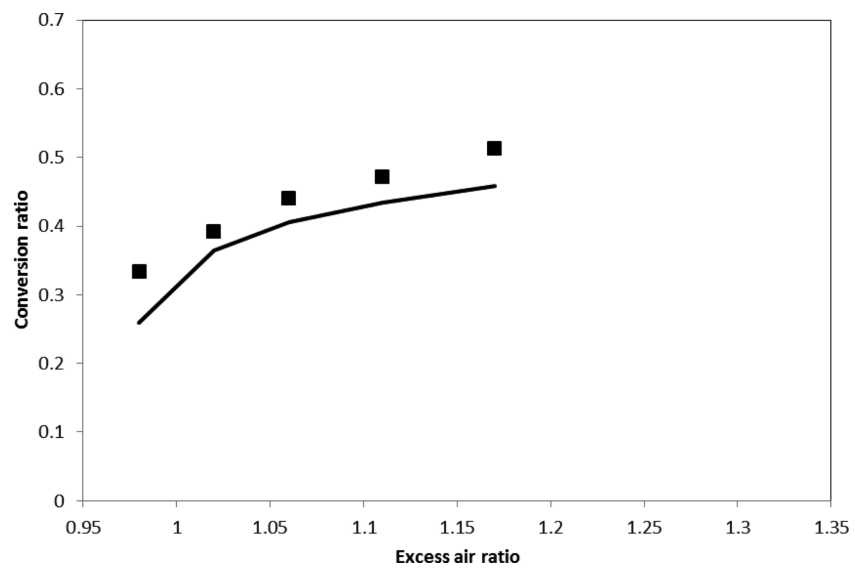

Figure 3. Comparison of measured and predicted fuel-N to NO ratios as a function of the excess air ratio and the feed ratio in the oxy-fuel combustion of coal in an EFR. The experimental data (present work) are shown as symbols, while the modeling predictions are shown as lines. The experiments were conducted with a Polish bituminous coal (Bit 1, $21 \mu \mathrm{m}$ ) at a wall temperature of $1623 \mathrm{~K}$ and a gas residence time of $2.3 \mathrm{~s}$.

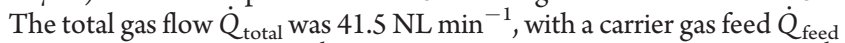
for the coal of $12 \mathrm{NL} \mathrm{min}^{-1}$. The coal feeding rate was $6.7-8.0 \mathrm{~g} \mathrm{~min}^{-1}$. The primary gas consisted of pure $\mathrm{O}_{2}$, while the secondary flow contained $\mathrm{O}_{2}$ in $\mathrm{CO}_{2}$, with a small amount of $\mathrm{N}_{2}$.

For reference, selected combustion experiments were conducted in air. Figure 2 compares the experimental results and modeling predictions for conventional combustion of coal in air. In these experiments, the excess air ratio $\lambda$ was varied in the range $1.0-1.35$. Furthermore, the feed ratio $R_{\mathrm{f}}$, defined as primary gas flow to total gas flow, was varied between 21 and 30\% (vol). Air was used for both primary and secondary flows. To compensate for the effect of dilution, the results are shown in terms of the conversion ratio for fuel-N to NO.

The results confirm expectations that the leaner mixtures result in a larger NO formation. In addition, the $\mathrm{NO}$ yield increases considerably with the feed ratio, from a conversion of about $40 \%$ (about $900 \mathrm{ppm}$ ) at $R_{\mathrm{f}}=0.21$ to $60 \%$ (about $1300 \mathrm{ppm}$ ) at $R_{\mathrm{f}}=0.30$, both at excess air ratios of 1.17 .

Because the primary and secondary flows are initially segregated, it is important to estimate a mixing rate for use in the model. Initially, the fuel jet experiences reducing conditions, but as the secondary flow is entrained, there is a rich-lean transition and the burnout takes place under oxidizing conditions. In the model, the secondary stream is gradually entrained into the primary stream containing the coal particles. To evaluate the (laminar) mixing rate $k$, it is necessary to estimate the required time to achieve a nearly fully mixed mixture. To this aim, a CFD simulation using the commercial software code Fluent was performed. The simple predefined coal combustion model in Fluent was activated, and to track the mixing process quantitatively, a small amount of argon was introduced through the secondary flow. The mixing was considered to be complete when a roughly uniform concentration of argon in the radial direction was achieved. On the basis of the simulations, an average value of $k_{\text {mixing }}=5.7 \mathrm{~s}^{-1}$ has been obtained and used in the modeling of the air-fired EFR experiments, independent of configuration. For the oxy-fuel experiments discussed below, a value of $k_{\text {mixing }}=11.7 \mathrm{~s}^{-1}$ was derived from CFD (see the Supporting Information).

As seen in Figure 2, the modeling predictions are in good agreement with the measured results for the higher feed ratios.

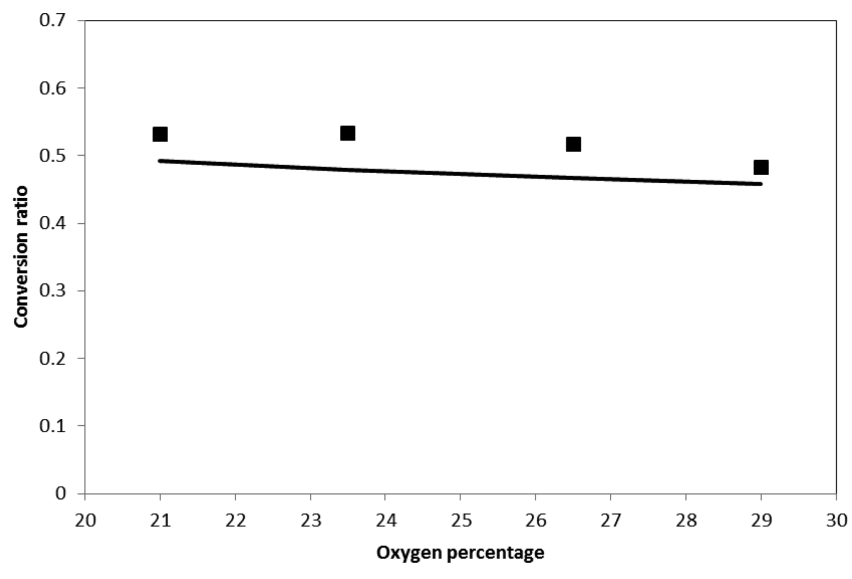

Figure 4. Comparison of measured and predicted fuel-N to NO ratios as a function of $\left[\mathrm{O}_{2}\right]$ in the oxidizer, in the oxy-fuel combustion of coal in an EFR. The experimental data (present work) are shown as symbols, while the modeling predictions are shown as lines. The experiments were conducted with a Polish bituminous coal (Bit 1,21 $\mu \mathrm{m}$ ) at a wall temperature of $1623 \mathrm{~K}$ and a gas residence time of $1.7-2.3 \mathrm{~s}$. The overall excess air ratio $\lambda$ was 1.17 . The total gas flow $\dot{Q}_{\text {total }}$ was $41.5-57.3 \mathrm{NL}$ $\min ^{-1}$, with a carrier gas feed $\dot{Q}_{\text {feed }}$ for the coal of $12 \mathrm{NL} \min ^{-1}$. The coal feeding rate was $6.7 \mathrm{~g} \mathrm{~min}^{-1}$.

However, while the model captures the trend in $\mathrm{NO}$ as a function of both excess air ratio and feed ratio, it underpredicts the observed impact of the feed ratio. This may indicate that the simplified mixing approach used in the model, with the same entrainment rate used for all three feed ratios, is insufficient to provide quantitative predictions of NO.

Figure 3 compares the experimental results and modeling predictions for the oxy-fuel combustion of coal, showing the variation of the $\mathrm{NO}$ conversion ratio versus the excess air ratio. These data were obtained under once-through conditions, that is, without recirculation and without $\mathrm{NO}$ being present in the inlet gas. The results are not directly comparable to the conventional combustion of Figure 2 because the primary jet, for safety reasons, consisted only of $\mathrm{CO}_{2}$, while all the $\mathrm{O}_{2}$ was supplied in the secondary flow, containing a mixture of $\mathrm{O}_{2}$ and $\mathrm{CO}_{2}$. Furthermore, the total $\mathrm{O}_{2}$ level after mixing has been increased to $29 \%$. Figure 3 shows that the trend in $\mathrm{NO}$ as a function of the excess air ratio is similar to that observed in air. The model captures the trend in NO with excess air ratio well but slightly underestimates the absolute level in NO.

In Figure 4, the effect of increasing the oxygen concentration in the oxidizer at constant overall excess air ratio is shown. The $\mathrm{O}_{2}$ increase is obtained by increasing the feed of inert gas $\left(\mathrm{CO}_{2}\right)$ into the reactor and, at the same time, changing the composition of the main stream. The conversion ratio of fuel- $\mathrm{N}$ to $\mathrm{NO}$ decreases slightly as the $\mathrm{O}_{2}$ content is increased. The model captures the trend in $\mathrm{NO}$ well but, again, slightly underestimates the absolute level of NO.

EFR Results from the Literature. In addition to the experiments performed as part of the present work, the model was tested against the entrained flow reactor results reported by $\mathrm{Hu}$ et al. ${ }^{8}$ and Jiang et al. ${ }^{11}$ Similar to the experiments presented above, these tests were conducted in once-through reactors. However, both $\mathrm{Hu}$ et al. and Jiang et al. chose to fully premix the fuel and oxidizer before it entered the heated zone of the reactor. This way, the complication of describing the mixing process in the model is avoided, but the conditions bear less resemblance 


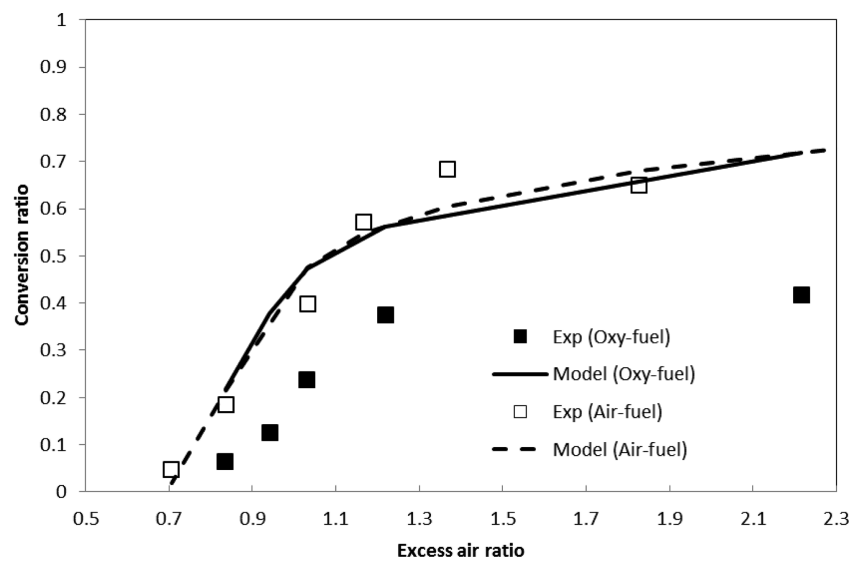

Figure 5. Comparison of measured and predicted fuel-N to NO ratios as a function of the excess air ratio and oxidizer composition $\left(20 \% \mathrm{O}_{2}\right.$ in $\mathrm{N}_{2}$ or $\mathrm{CO}_{2}$ ) in pulverized combustion of coal in an EFR. The experimental data ${ }^{8}$ are shown as symbols, while the modeling predictions are shown as lines. The experiments were conducted with a highly volatile bituminous coal (Bit 2, 60-125 $\mu \mathrm{m}$ ) at a wall temperature of $1423 \mathrm{~K}$ and a gas residence time of $2 \mathrm{~s}$.

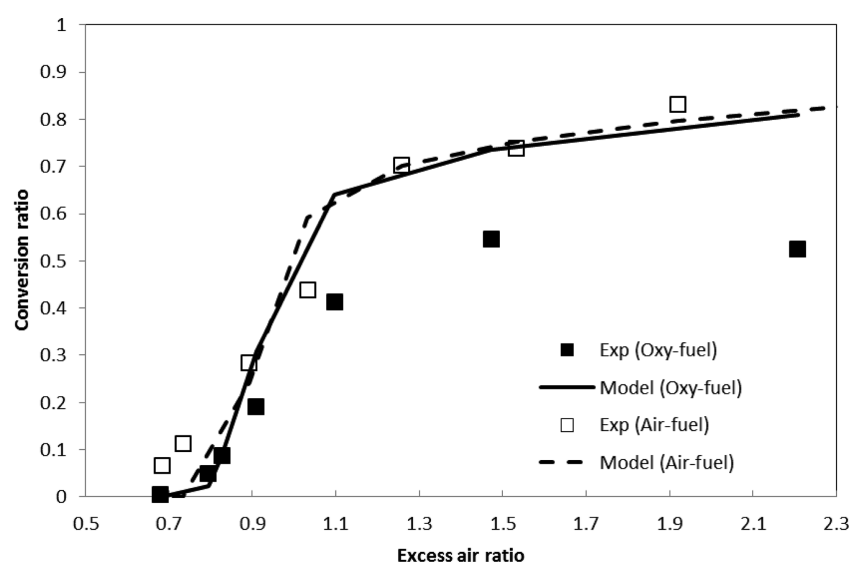

Figure 6. Comparison of measured and predicted fuel- $\mathrm{N}$ to $\mathrm{NO}$ ratios as a function of the excess air ratio and oxidizer composition (air or $20 \% \mathrm{O}_{2}$ in $\mathrm{CO}_{2}$ ) in pulverized combustion of coal in an EFR. The experimental data ${ }^{8}$ are shown as symbols, while the modeling predictions are shown as lines. The experiments were conducted with a highly volatile bituminous coal (Bit 2, $60-125 \mu \mathrm{m})$ at a wall temperature of $1573 \mathrm{~K}$ and a gas residence time of $2 \mathrm{~s}$.

to those of a practical pulverized-fuel burner with air staging. $\mathrm{Hu}$ et al. and Jiang et al. tested a wider range of coals, and their experiments generally operated at lower temperatures compared to those of the present work.

$\mathrm{Hu}$ et al. ${ }^{8}$ investigated pollutant formation in the combustion of a highly volatile bituminous coal (Bit 2), testing the effect of inert gas $\left(\mathrm{N}_{2}\right.$ or $\left.\mathrm{CO}_{2}\right)$, oxygen concentration $(20-100 \%)$, and temperature $(1173-1573 \mathrm{~K})$. Figures 5 and 6 show the effect of replacing $\mathrm{N}_{2}$ with $\mathrm{CO}_{2}$ at reactor temperatures of 1423 and $1573 \mathrm{~K}$, respectively. We focus on the results obtained in the higher end of the temperature window, as they are more representative of pulverized-fuel combustion.

In line with observations from the EFR experiments of the present work, the conversion of fuel-N to NO is seen to increase monotonically with the excess air ratio at both temperatures.

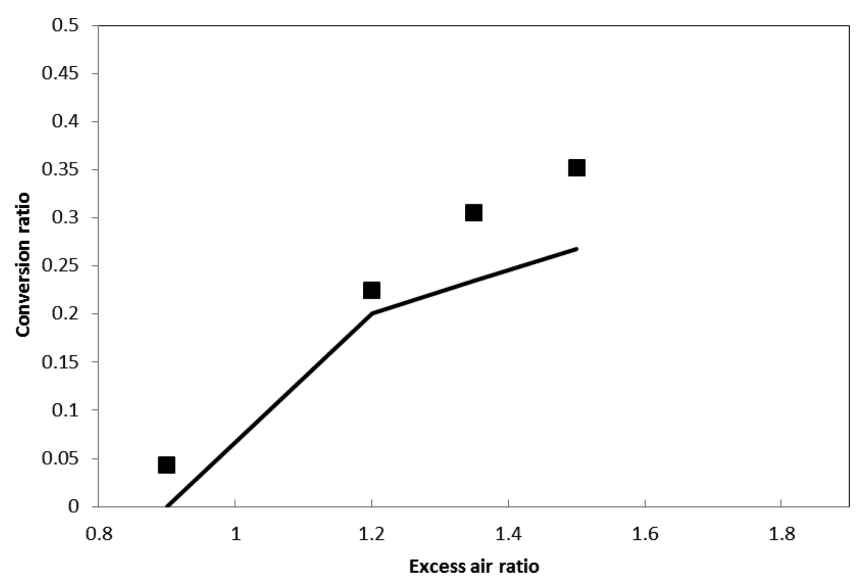

Figure 7. Comparison of measured and predicted fuel-N to NO ratios as a function of the excess air ratio in pulverized combustion of coal in an EFR. The experimental data ${ }^{11}$ are shown as symbols, while the modeling predictions are shown as lines. The inlet gas composition was $35 \% \mathrm{O}_{2}$ in $\mathrm{CO}_{2}$. The experiments were conducted with Tiefa bituminous coal (Bit 3, $15 \mu \mathrm{m}$; raw coal feeding rate of $1 \mathrm{~g} \mathrm{~min}^{-1}$ ) at a maximum wall temperature of $1373 \mathrm{~K}$ and a gas residence time of 3.6-5.9 s.

At lean conditions, the NO yield is a weak function of the excess air ratio, but at fuel-rich conditions, NO decreases strongly, approaching zero at $\lambda=0.7$. An increase in the reactor temperature results in a slightly larger NO yield. Contrary to what was observed in our experiments, here, the $\mathrm{NO}$ yield at high $\mathrm{CO}_{2}$ levels is significantly smaller than it is for combustion in $\mathrm{N}_{2}$. Under the conditions reported by $\mathrm{Hu}$ et al., $\mathrm{NO}$ is reduced by about $30 \%$ going from air to $\mathrm{O}_{2} / \mathrm{CO}_{2}$ mixtures. The difference is even more pronounced at lower temperatures $(1173-1273 \mathrm{~K}$, not shown), where the $\mathrm{NO}$ yield in $\mathrm{CO}_{2}$ is a factor of 2 lower than that in $\mathrm{N}_{2}{ }^{8}$.

The modeling predictions are in excellent agreement with the reported NO yield for combustion in air, at both 1423 and $1573 \mathrm{~K}$. However, the observed impact of replacing $\mathrm{N}_{2}$ with $\mathrm{CO}_{2}$ is not captured by the model, which predicts little difference in $\mathrm{NO}$ between $\mathrm{N}_{2}$ and $\mathrm{CO}_{2}$ atmospheres. The reason for this discrepancy is not clear. $\mathrm{Hu}$ et al. attribute the smaller $\mathrm{NO}$ yield in $\mathrm{O}_{2} / \mathrm{CO}_{2}$ mostly to the enhanced $\mathrm{CO}$ concentrations in the oxyfuel combustion, promoting the reduction of $\mathrm{NO}$ by $\mathrm{CO}$ in a charcatalyzed reaction. This step is not considered in the present model because it would be expected to be less important than the direct reaction of $\mathrm{NO}$ with char at the high temperatures typical of pulverized fuel combustion. ${ }^{45}$

The smaller $\mathrm{NO}$ yield in $\mathrm{CO}_{2}$ could also be caused by the chemical effect of $\mathrm{CO}_{2}$ on the gas-phase chemistry. Mendiara and Glarborg ${ }^{7}$ report differences in $\mathrm{NO}$ formation for oxidation of $\mathrm{CH}_{4} / \mathrm{NH}_{3}$ mixtures burned in $\mathrm{O}_{2} / \mathrm{N}_{2}$ and $\mathrm{O}_{2} / \mathrm{CO}_{2}$ mixtures, respectively, at temperatures as low as $1273 \mathrm{~K}$. They show that $\mathrm{CO}_{2}$ inhibits $\mathrm{NO}$ formation under oxidizing conditions, consistent with the observations of $\mathrm{Hu}$ et al., but enhances $\mathrm{NO}$ under reducing conditions. The fact that this effect is not found in the present modeling is due to the assumed volatile composition with a low hydrocarbon yield. In the model, which was developed for high-temperature pulverized-fuel combustion, tar is assumed to crack to form soot and $\mathrm{H}_{2}$. Pyrolysis experiments show that the soot/tar yields are constant in the temperature range 1480$1900 \mathrm{~K} ;{ }^{39,40}$ however, the soot fraction decreases with decreasing 


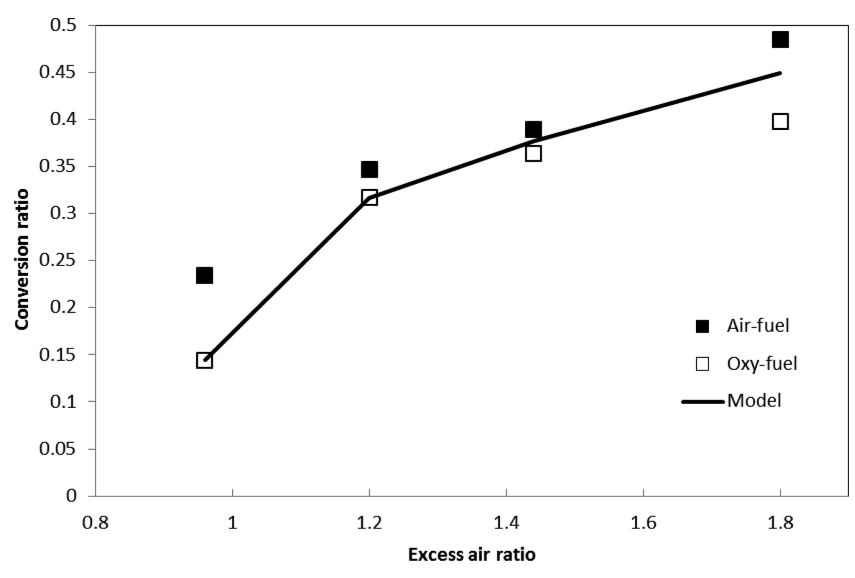

Figure 8. Comparison of measured and predicted fuel-N to NO ratios as a function of the excess air ratio and the oxidizer composition $\left(35 \% \mathrm{O}_{2}\right.$ in $\mathrm{N}_{2}$ or $\mathrm{CO}_{2}$ ) in the pulverized combustion of coal in an EFR. The experimental data ${ }^{11}$ are shown as symbols, while the modeling predictions are shown as lines. The experiments were conducted with Neimenggu lignite $\left(5 \mu \mathrm{m}\right.$; raw coal feeding rate of $\left.1 \mathrm{~g} \mathrm{~min}^{-1}\right)$ at a maximum wall temperature of $1373 \mathrm{~K}$ and a gas residence time of $3.0-5.4 \mathrm{~s}$.

temperature and may be overestimated by the model at the conditions of Figures 5 and 6.

Jiang et al. ${ }^{11}$ investigated NO formation in oxy-fuel combustion of three different solid fuels: bituminous coal, lignite, and anthracite. For the present purposes, we have selected results obtained for the bituminous coal (Tiefa, Bit 3 ) and the lignite (Neimenggu) for model comparison because these two fuels have a greater practical interest than anthracite.

The experimental results of Jiang et al. ${ }^{11}$ for the bituminous coal under simulated oxy-fuel conditions are compared with model predictions in Figure 7. Similar to the results from the present work and from Hu et al., the measurements show the NO conversion ratio to increase with the excess air ratio. The NO yield is smaller than that reported by Hu et al., consistent with the lower temperatures of the study of Jiang et al.

In the calculations, the flow rate of the gases in every location was estimated from the reactor temperature-time profile obtained from the reported temperature-location data. The residence time of the gases was then estimated in accordance to velocities obtained from the reported temperature at every location. The modeling predictions are in satisfactory agreement with the experimental data, even though NO is slightly underpredicted at high excess air ratios.

Figure 8 compares the experimental data for the lignite with the modeling predictions. In contrast to the findings of $\mathrm{Hu}$ et al., the impact of oxidizer composition $\left(\mathrm{O}_{2} / \mathrm{N}_{2}\right.$ or $\left.\mathrm{O}_{2} / \mathrm{CO}_{2}\right)$ is quite small under these conditions. A distinctive influence of the gas mixture is seen only at high excess air ratios, where the measured $\mathrm{NO}$ yield is slightly larger in air compared to that in $\mathrm{O}_{2} / \mathrm{CO}_{2}$. The model is in good agreement with the reported data. The calculations support the observation of Jiang et al. that replacing $\mathrm{N}_{2}$ with $\mathrm{CO}_{2}$ does not affect the NO level significantly under these conditions.

In practice, oxy-fuel combustion involves recirculation of flue gases. Under these conditions, considerable amounts of NO are present in the oxidizer and reburn type reactions are important for reducing the overall $\mathrm{NO}$ yield. ${ }^{2}$ Figure 9 compares experimental results from Jiang et al. with modeling predictions for conditions where NO in the inlet gas varied in the range $0-1200 \mathrm{ppm}$.

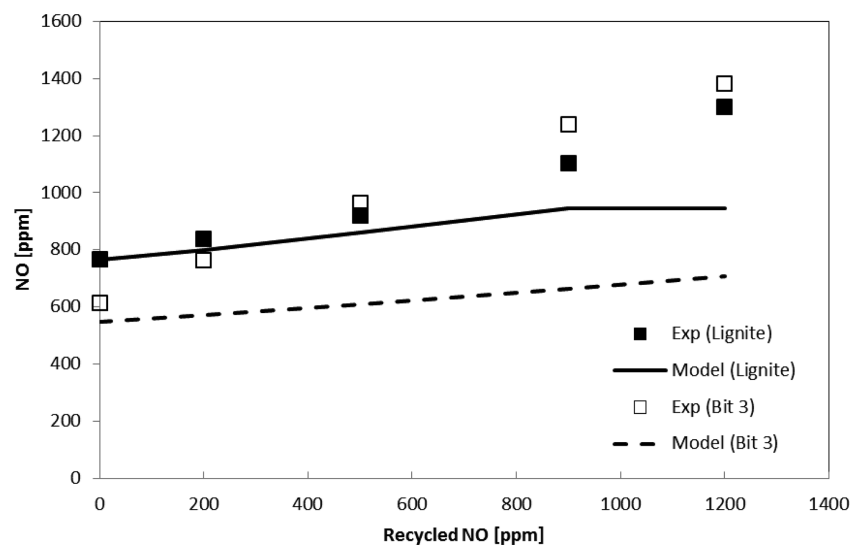

Figure 9. Comparison of measured and predicted NO molar fractions as a function of the inlet $\mathrm{NO}$ level in the pulverized combustion of coal under oxy-fuel conditions in an EFR. The experimental data ${ }^{11}$ are shown as symbols, while the modeling predictions are shown as lines. The inlet gas composition was $35 \% \mathrm{O}_{2}$ in $\mathrm{CO}_{2}$. The experiments were conducted at an excess air ratio of 1.2 with Neimenggu lignite and Tiefa bituminous coal (Bit 3, $15 \mu \mathrm{m}$; raw coal feeding rate of $1 \mathrm{~g} \mathrm{~min}^{-1}$ ) at a maximum wall temperature of $1373 \mathrm{~K}$ and a gas residence time of $4.4 \mathrm{~s}$.

The NO exhaust level increases with inlet NO. However, despite the overall lean conditions, a reduction of NO takes place. For the bituminous coal (Bit 3), inlet NO is reduced about 30\%, while, for lignite, the reduction is almost $60 \%$. The modeling conditions are qualitatively in agreement with the experimental results. However, the model overestimates the reduction in NO, with the overestimation most pronounced for the bituminous coal. Because the conditions are overall lean, the homogeneous reduction of NO would be expected to be limited. ${ }^{6,45}$ The difference observed between the two fuels is consistent with observations that lignite char is more reactive toward NO than bituminous coal. ${ }^{28}$ However, a NO rise because of higher NO content in the inlet was not predicted by the model.

Model Evaluation and Key Reaction Paths. Despite its deficiencies, the model generally provides a satisfactory description of the nitrogen chemistry in the oxy-fuel combustion of pulverized coal under the conditions investigated. It describes correctly the effect of process parameters such as temperature, excess air ratio, and inlet NO. An analysis of the modeling calculations is helpful to get a better understanding of NO formation and reduction under oxy-fuel conditions. The formation of NO is constrained by the availability of oxygen, which is important for the oxidation selectivity of the volatile $\mathrm{N}$ to $\mathrm{NO}$ and $\mathrm{N}_{2}$. Nitric oxide, once formed, may be reduced by reaction with hydrocarbon radicals or in heterogeneous reactions by char or soot. While this overall scheme is well established, ${ }^{45}$ the relative importance of the specific pathways under oxy-fuel conditions is still in question.

Figure 10 shows the sensitivity of the model predictions to selected subsets in the model for the conditions of Figure 6, that is, oxy-fuel combustion with a bituminous coal at $1573 \mathrm{~K}$. The importance of soot was tested either by retaining soot as a species but disabling the soot $+\mathrm{NO}$ reaction (shown in the figure) or by changing the volatile composition and replacing soot (and some $\mathrm{H}_{2}$ ) with $\mathrm{C}_{2} \mathrm{H}_{2}$ (not shown). The two sets of calculations were practically identical, indicating that, under the investigated conditions, hydrocarbons are not very efficient in reducing NO. 


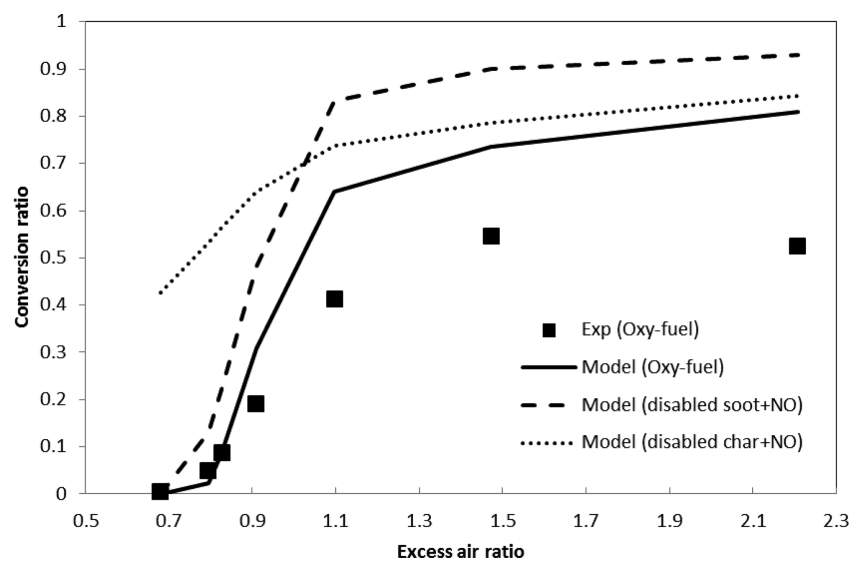

Figure 10. Sensitivity to model predictions of selected heterogeneous reactions for the conditions of Figure 6 (oxy-fuel).

The modeling results of Figure 10 confirm that heterogeneous reactions are important for the modeling predictions. Soot is active in reacting with $\mathrm{NO}$ under both oxidizing and reducing conditions. It has a high reactivity toward $\mathrm{NO}$ and also toward $\mathrm{O}_{2}$; the latter reaction serves to limit the lifetime of soot, even under overall reducing conditions. The reaction of char with NO is slower, but it attains significance, particularly under reducing conditions, where the char is not fully oxidized. The fact that the model for these conditions overpredicts $\mathrm{NO}$ in $\mathrm{CO}_{2}$ but not in $\mathrm{N}_{2}$ may indicate that the high CO levels in oxy-fuel combustion enhance the reduction of NO by $\mathrm{CO}$ on char surfaces.

A similar analysis for the conditions of Figure 3 confirms that, under overall lean conditions, char $+\mathrm{NO}$ is the main reaction for removal of NO. In the absence of the char $+\mathrm{NO}$ reaction, the model overestimates the NO yield and no longer predicts correctly the effect of excess ratio. Despite high soot yields, reactions involving soot have a smaller impact, because soot is rapidly oxidized.

Another important parameter in the model for the conditions of Figure 3 is the assumed mixing rate between the primary and secondary jet. Varying the mixing rate between instantaneous mixing and mixing times on the order of a second results in differences in the predicted $\mathrm{NO}$ concentration of a factor of 5 , decreasing from about $1500 \mathrm{ppm}$ at fast mixing conditions to about $300 \mathrm{ppm}$. This emphasizes the need for a satisfactory model for the mixing process for quantitative predictions of NO in pulverized fuel burners.

With NO present in the inlet gas, reburn type reactions become even more important. Figure 11 shows the sensitivity of the model predictions to the reduction of $\mathrm{NO}$ by char and soot, respectively, in the model for the lignite under the conditions of Figure 9. Again, heterogeneous reactions are important for the modeling results. The formation of soot limits the hydrocarbon volatile yield; however, this is compensated for by reduction of $\mathrm{NO}$ on soot, which appears to be very efficient. The predicted impact of soot for reducing NO is in agreement with modeling studies for coal reburning. ${ }^{28}$

It is interesting to note that the results of the present work are in conflict with a previous analysis of the nitrogen chemistry in oxy-fuel combustion. From experiments performed in a small-scale laboratory reactor, Okazaki and Ando ${ }^{77}$ evaluated the relative impact of homogeneous and heterogeneous mechanisms for NO reduction. They concluded that reburn type

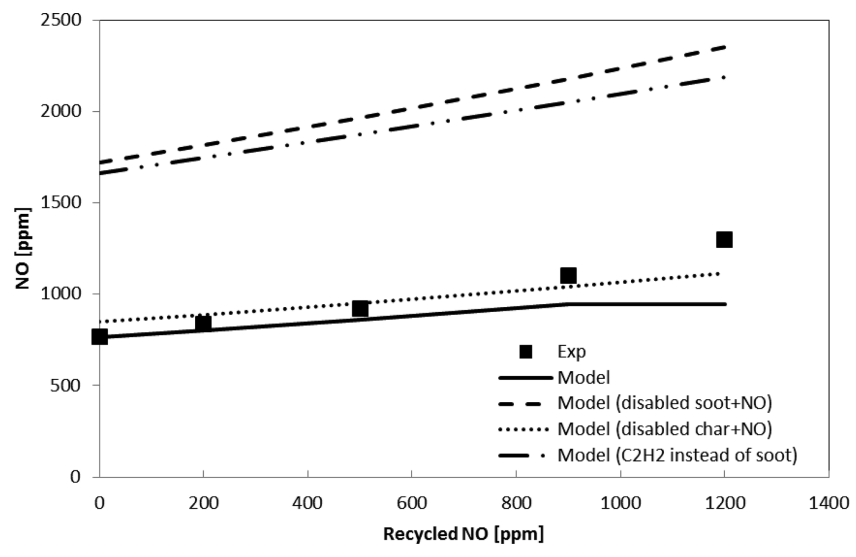

Figure 11. Sensitivity to model predictions of selected heterogeneous reactions for the conditions of Figure 9.

reactions, that is, reactions of recycled $\mathrm{NO}$ with hydrocarbons, are the dominant mechanism in reducing $\mathrm{NO}$ emissions and that they account for $50-80 \%$ of the decrease in NO observed in oxyfuel combustion. Reactions of $\mathrm{NO}$ with $\mathrm{N}$-volatiles were estimated to contribute $10-50 \%$ to the NO reduction. The reduction of NO on char in oxy-fuel combustion was found to be of minor importance, and the reaction between $\mathrm{NO}$ and soot was not considered. While these results are consistent with data for oxy-fuel combustion of $\mathrm{CH}_{4},{ }^{6,7}$ they may not be applicable to solid fuel combustion at high temperatures. The analysis of Okazaki and Ando could be biased by the choice of a $\mathrm{CH}_{4}$ / $\mathrm{NH}_{3}$ mixture to simulate coal volatiles, together with a low reactivity char (formed from anthracite) to account for heterogeneous reactions. We think, on the basis of the present work, that the heterogeneous reduction of $\mathrm{NO}$ on char and soot is a major mechanism for NO removal in oxy-fuel combustion of pulverized coal and that the homogeneous mechanisms are less important.

\section{- CONCLUSIONS}

On the basis of the analysis of the modeling results, a number of important points can be made. Differences in NO yield between the oxy-fuel combustion and the conventional combustion of pulverized coal can mostly be attributed to the recycling of NO (reburning effect) and to changes in mixing patterns between fuel and oxygen. For pulverized-fuel combustion at high temperatures, we think that $\mathrm{NO}$ is mainly reduced by heterogeneous reactions involving both char and soot. Here, the tar yield of the volatiles is mainly converted to soot and $\mathrm{H}_{2}$, limiting the concentration of hydrocarbons and, thereby, limiting the importance of gas-phase removal of NO. Under these conditions, the large concentration of $\mathrm{CO}_{2}$ in oxy-fuel combustion has, at most, a limited impact on $\mathrm{NO}$ formation and destruction. At lower temperatures, where the hydrocarbon yield in devolatilization increases, the impact of $\mathrm{CO}_{2}$ on the gas-phase chemistry may become more pronounced, enhancing or inhibiting NO formation depending on stoichiometry. Also, the increased CO levels under oxy-fuel conditions may conceivably promote the reduction of $\mathrm{NO}$ by $\mathrm{CO}$ on char, even at the high temperatures in pulverized fuel combustion.

\section{ASSOCIATED CONTENT}

s Supporting Information. CHEMKIN format model information and experimental conditions for the oxy-fuel experiment 
in an EFR. This material is available free of charge via the Internet at http://pubs.acs.org.

\section{AUTHOR INFORMATION}

\section{Corresponding Author}

*E-mail: pgl@kt.dtu.dk.

\section{ACKNOWLEDGMENT}

The work was part of the OXYVAL project, funded by Vattenfall $\mathrm{AB}$ and Alstom Power Systems GmbH.

\section{REFERENCES}

(1) Buhre, B. J. P.; Elliot, L. K.; Sheng, C. D.; Gupta, R. P.; Wall, T. F. Prog. Energy Combust. Sci. 2005, 31, 283-307.

(2) Toftegaard, M. B.; Brix, J.; Jensen, P. A.; Glarborg, P.; Jensen,

A. D. Prog. Energy Combust. Sci. 2010, 36, 581-625.

(3) Horn, F. L.; Steinberg, M. Fuel 1982, 61, 415-422.

(4) Abraham, B. M.; Asbury, J. G.; Lynch, E. P.; Teotia, A. P. S. Oil Gas J. 1982, 80, 68.

(5) Normann, F.; Andersson, K.; Leckner, B.; Johnsson, F. Prog. Energy Combust. Sci. 2009, 35, 365-397.

(6) Mendiara, T.; Glarborg, P. Energy Fuels 2009, 23, 3565-3572.

(7) Mendiara, T.; Glarborg, P. Combust. Flame 2009, 156, 19371949.

(8) Hu, Y.; Naito, S.; Kobayashi, N.; Hasatani, M. Fuel 2000, 79, 1925-1932.

(9) Hu, Y. Q.; Kobayashi, N.; Hasatani, M. Fuel 2001, 80, 1851-1855.

(10) Hu, Y. Q.; Kobayashi, N.; Hasatani, M. Energy Convers. Manage. 2003, 44, 2331-2340.

(11) Jiang, X.; Huang, X.; Liu, J.; Han, X. Energy Fuels 2010, 24, 6307-6313.

(12) Zhang, Y.; Zhang, J.; Sheng, C.; Liu, Y.; Zhao, L.; Ding, Z. Energy Fuels 2011, 25, 1146-1152.

(13) Croiset, E.; Thambimuthu, K. V.; Palmer, A. Can. J. Chem. Eng. 2000, 78, 402-407.

(14) Croiset, E.; Thambimuthu, K. V. Fuel 2001, 80, 2117-2121.

(15) Liu, H.; Zailani, R.; Gibbs, B. M. Fuel 2005, 84, 833-840.

(16) Farley, M. Mod. Power Syst. 2006, 26, 20.

(17) Andersson, K.; Normann, F.; Johnsson, F.; Leckner, B. Ind. Eng. Chem. Res. 2008, 47, 1835-1845.

(18) Hjartstam, S.; Andersson, K.; Johnsson, F.; Leckner, B. Fuel 2009, 88, 2216-2224.

(19) Skeen, S. A.; Scott, A.; Kumfer, B. M.; Axelbaum, R. L. Energy Fuels 2010, 24, 4144-4152.

(20) Kuhnemuth, D.; Normann, F.; Andersson, K.; Johnsson, F.; Leckner, B. Energy Fuels 2011, 25, 624-631.

(21) Liu, H.; Qiu, J. R.; Xu, Z. Y.; Cheng, B.; Wu, H.; Kong, F. H.;

Liu, Z. H. Proc. Int. Symp. Coal Combust. 2010, 6, 142-147.

(22) Cao, H. L.; Sun, S. Z.; Liu, Y. H.; Wall, T. F. Energy Fuels 2010, 24, 131-135.

(23) Zhao, R.; Liu, H.; Hu, H.; Zhong, X.; Wang, Z.; Xu, Z.; Qiu, J. Sci. China, Ser. E: Technol. Sci. 2010, 53, 3275-3283.

(24) Pedersen, L. S.; Glarborg, P.; Dam-Johansen, K. Combust. Sci. Technol. 1998, 131, 193-223.

(25) Hansen, S.; Glarborg, P. Energy Fuels 2010, 24, 2883-2890.

(26) Hansen, S.; Glarborg, P. Energy Fuels 2010, 24, 4185-4192.

(27) Pedersen, K. H.; Jensen, A. D.; Dam-Johansen, K. Combust. Flame 2010, 157, 208-216.

(28) Østberg, M.; Glarborg, P.; Jensen, A.; Johnsson, J. E.; Pedersen, L. S.; Dam-Johansen, K. Proc. Combust. Inst. 1998, 23, 3027-3035.

(29) Vilas, E.; Skifter, U.; Jensen, A. D.; Glarborg, P.; Lopez, C.; Maier, J. Energy Fuels 2004, 18, 1442-1450.

(30) Alzueta, M. U.; Bilbao, R.; Millera, A.; Glarborg, P.; Østberg, M.; Dam-Johansen, K. Energy Fuels 1998, 12, 329-338.
(31) Glarborg, P.; Kristensen, P. G.; Dam-Johansen, K.; Alzueta, M. U.; Millera, A.; Bilbao, R. Energy Fuels 2000, 14, 828-838.

(32) Zwietering, Th. N. Chem. Eng. Sci. 1959, 11, 1-15.

(33) Grcar, J. F.; Glarborg, P.; Bell, J. B.; Day, M. S.; Loren, A.; Jensen, A. D. Proc. Combust. Inst. 2005, 30, 1193-1200.

(34) Niksa, S.; Lau, C.-W. Combust. Flame 1993, 94, 293-307.

(35) Kobayashi, H.; Howard, J. B.; Sarofim, A. F. Proc. Combust. Inst. 1977, 16, 411-425.

(36) Fletcher, T. H. Combust. Flame 1989, 78, 223-236.

(37) Ubhayakar, S. K.; Stickler, D. B.; Von Rosenberg, C. W., Jr.; Gannon, R. E. Proc. Combust. Inst. 1977, 16, 427-436.

(38) Niksa, S.; Cho, S. Energy Fuels 1996, 10, 463-473.

(39) Chen, J. C.; Castagnoli, C.; Niksa, S. Energy Fuels 1992, 6, 264-271.

(40) Ma, J. Soot formation during coal pyrolysis. Ph.D. Thesis, Department of Chemical Engineering, Brigham Young University, 1996.

(41) Solomon, P. R.; Fletcher, T. H. Proc. Combust. Inst. 1994, $25,463-474$.

(42) Neoh, K. G.; Gannon, R. E. Fuel 1984, 63, 1347-1352.

(43) Suuberg, E. M.; Peters, W. A.; Howard, J. B. Ind. Eng. Chem. Process Des. Dev. 1978, 17, 37-46.

(44) Chen, J. C.; Niksa, S. Proc. Combust. Inst. 1992, 24, 1269-1276.

(45) Glarborg, P.; Jensen, A. D.; Johnsson, J. E. Prog. Energy Combust. Sci. 2003, 29, 89-113.

(46) Pohl, J. H.; Sarofim, A. F. Proc. Combust. Inst. 1977, 16, 491-501.

(47) Pedersen, L. S.; Glarborg, P.; Dam-Johansen, K.; Hepburn,

P. W.; Hesselmann, G. Combust. Sci. Technol. 1998, 132, 251-314.

(48) Glarborg, P.; Bentzen, L. L. B. Energy Fuels 2008, 22, 291-296.

(49) Skreiberg, O.; Kilpinen, P.; Glarborg, P. Combust. Flame 2004, 136, 501-508.

(50) Tian, Z.; Li, Y.; Zhang, L.; Glarborg, P.; Qi, F. Combust. Flame 2009, 156, 1413-1426.

(51) Rasmussen, C. L.; Hansen, J.; Marshall, P.; Glarborg, P. Int. J. Chem. Kinet. 2008, 40, 454-480.

(52) Rasmussen, C. L.; Jacobsen, J. G.; Glarborg, P. Int. J. Chem. Kinet. 2008, 40, 778-807.

(53) Dagaut, P.; Glarborg, P.; Alzueta, M. U. Prog. Energy Combust. Sci. 2008, 34, 1-46.

(54) Glarborg, P.; Alzueta, M. U.; Dam-Johansen, K.; Miller, J. A. Combust. Flame 1998, 115, 1-27.

(55) Rasmussen, C. L.; Jacobsen, J. G.; Glarborg, P. Combust. Flame 2008, 154, 529-545.

(56) Nagle, J.; Strickland-Constable, R. F. Oxidation of Carbon between 1000-2000 ${ }^{\circ} \mathrm{C}$. Proc. Fifth Carbon Conf. 1962, 1, 154-164.

(57) Neoh, K. G.; Howard, J. B.; Sarofim, A. F. Particulate Carbon Formation during Combustion; Siegla, D. C., Smith, G. W., Eds.; John Wiley \& Sons: 1981.

(58) von Gersum, S.; Roth, P. Proc. Combust. Inst. 1992, 24, 999-1006.

(59) Cheng, M. T.; Kirsch, M. J.; Lester, T. W. Combust. Flame 1989, 77, 213-217.

(60) Brix, J.; Jensen, P. A.; Jensen, A. D. Fuel 2011, 89, 3373-3380.

(61) Smith, I. W. Fuel 1978, 57, 409-414.

(62) Smith, I. W. Proc. Combust. Inst. 1982, 19, 1045-1065.

(63) Thiele, E. W. Ind. Eng. Chem. 1939, 31, 916-920.

(64) Johnsson, J. E.; Jensen, A. D. Proc. Combust. Inst. 2000, 28, 2353-2359.

(65) Song, Y. H.; Beer, J. M.; Sarofim, A. F. Combust. Sci. Technol. 1981, 25, 237-240.

(66) Aarna, I.; Suuberg, E. M. Fuel 1997, 76, 475-491.

(67) Baumann, H.; Schuler, J.; Schiller, R. Erdol Erdgas Kohle 1989, $105,227-232$.

(68) Ninomiya, Y.; Yokoi, K.; Arai, N.; Hasatani, M. Int. Chem. Eng. $1989,29,512-516$.

(69) Miettinen, H.; Paulsson, M.; Strömberg, D. Energy Fuels 1995, 9, 10-19.

(70) Jensen, L. S.; Jannerup, H. E.; Glarborg, P.; Jensen, A.; Dam-Johansen, K. Proc. Combust. Inst. 2000, 28, 2271-2278.

(71) Aihara, T.; Matsuoka, K.; Kyotani, T.; Tomita, A. Proc. Combust. Inst. 2000, 28, 2189-2195. 
(72) Ashman, P. J.; Haynes, B. S.; Nicholls, P. M.; Nelson, P. F. Proc. Combust. Inst. 2000, 28, 2171-2179.

(73) Aarna, I.; Suuberg, E. M. Proc. Combust. Inst. 1998, 27, 30613068.

(74) Guo, F.; Hecker, W. Proc. Combust. Inst. 1998, 27, 3085-3092.

(75) Garijo, E. G.; Jensen, A. D.; Glarborg, P. Combust. Flame 2004, 136, 249-253.

(76) CHEMKIN 4.1; Reaction Design, Inc.: San Diego, CA, 2010.

(77) Okazaki, K.; Ando, T. Energy 1997, 22, 207-215. 